\title{
Development and Evaluation of Composite Flour for Missi roti /chapatti
} Kadam ML, Salve RV, Mehrajfatema ZM* and More SG

Dept of Food Chemistry, MGM College of Food Technology, Aurangabad (MS) India

\begin{abstract}
The present research work on development and evaluation of composite flour for missi roti / chapati were carried out to develop the nutritious flours from various food commodities (wheat flour, chickpea, and soybean and methi leaves powder) to make good quality of chapaties. Four types of bends were acceptable. They were made from wheat flour, chickpea, full fat soy flour and methi powder in different ratio viz; ' $A$ ' wheat flour: chickpea flour (80:20). 'B' wheat flour: fullfat soy flour (90:10) 'C' wheat flour: chickpea flour: soy flour $(80: 10: 10)$ and 'D' wheat flour: chickpea flour: soy flour: methi leaves powder (75: 10: 10: 05). The proximate composition of blends used for preparation of various products contained higher amount of protein and other nutrients. They contained proteins (11.8 to $15.37 \%)$, fat (1.53 to $3.45 \%)$, fibre (1.24 to $2.05 \%)$, ash (2.08 to $2.70 \%)$ and carbohydrates (65.99 to $74.2 \%)$. These results showed that soy flour / chickpea flour alone or in combination, both increased the amount of protein significantly. Calcium, phosphorus and iron were found to increase on supplementation of chickpea, soy flour and methi powder. Iron was high in methi supplemented blend. All these blended flours were found to have good sensory quality characteristics of products as control. All these blended flours could be well stored in polyethylene bags or tin boxes for the period of 3 months without any deterioration of quality. The supplementation of $5 \%$ methi powder increased the nutritional quality of flour particularly in minerals (calcium and iron) and fibres.
\end{abstract}

Keywords: Wheat flour; Cowpea; Chapatti; Nutritional quality; Mineral value

\section{Introduction}

Wheat (Triticum aestivum) is the major food produce among all the cereal crops. It is a staple food of large segment of world population. Wheat is extensively used for production of flat breads [1] such as the steam-leavened chapatti, a major source of nutrients [2] and staple diet common to Pakistan, India, and some parts of Africa [3]. About $85 \%$ of wheat consumption in India is in the form of chapattis.

Legumes have been known as "a poor man's meat". They supply protein, complex carbohydrates, fibre and essential vitamins and minerals to the diet, which are low in fat and sodium and contain no cholesterol. Legumes have been identified as low glycaemic index food [4]. A low glycaemic index food are very important in the dietary treatment of diabetes mellitus, increases satiety, facilitate the control of food intake and has other health benefits for healthy subject in terms of post-prandial glucose and lipid metabolism [5]. Regular consumption of pulses may have important protective effects on risk for cardiovascular disease [6]. Due to social reasons, the Indian peoples heavily depend on pulses a source of proteins, vitamins and minerals in the daily diet. Chick pea, pigeon pea, mung bean, urad bean, lentil and field pea are the importance pulses of significant dietary importance. In addition to nutritional importance, they are also being recognized as having therapeutic and medicinal properties. Chickpea occupies first position among pulses representing $35 \%$ of total cultivated area of pulses and contributing $45 \%$ of total production in India. In Madhya Pradesh chickpea is grown in an area of 2.56 million hector with an annual production of 2.37 million tons.

Addition of legume and beans to cereal based products could be a good option for increasing the intake of legumes and beans. In addition, legume proteins are rich in lysine and deficient in sulphur containing amino acids, whereas cereal proteins are deficient in lysine, but have adequate amounts of sulphur amino acids [7]. Therefore, the combination of grain with legume proteins would provide better overall essential amino acid balance, helping to overcome the world protein calorie malnutrition problem [8]. Use of composite flour based on wheat and other cereals including minor millets in bakery products is becoming popular because of the economic and nutritional advantages [9]. The composite flours containing wheat and legumes are being utilized in many parts of the world. The basic composite flour technology refers to the process of mixing wheat flour with cereals and legumes to produce high quality food products in an economical way. Several studies about the influence of the addition of legume flours on the functional properties of bread dough and final bread quality have been reported in the last 30 years. Among the legumes tested, it is worth mentioning the addition of chickpea flour [10], germinated chickpea flour to wheat flour for obtaining bread. Even though the good results obtained with bread, those studies have not been extended to other cereal baked products. Hence the present work was planed with the objective to develop missi roti /chapatti from composite flour made from wheat, chickpea, soy flour and dried leafy vegetables. Nutritional characteristics, sensory quality and shelf life of the flour and products were studied.

\section{Materials and Methods}

Wheat, chickpea, soya bean were procured from local market of Aurangabd. All the chemicals and glassware's used in the present investigation were of standard companies (Merck and Borosil).

\section{Preparation of wheat flour}

Wheat grains were thoroughly cleaned to remove dirt, dust, insect

*Corresponding author: Mehrajfatema ZM, Dept of Food Chemistry, MGM College of Food Technology, Aurangabad (MS) India, E-mail: mehraj.udct@ gmail.com

Received October 25, 2011; Accepted November 22, 2011; Published December 02, 2011

Citation: Kadam ML, Salve RV, Mehrajfatema ZM, More SG (2012) Development and Evaluation of Composite Flour for Missi roti /chapatti. J Food Process Technol 3:134. doi:10.4172/2157-7110.1000134

Copyright: (c) 2012 Kadam ML, et al. This is an open-access article distributed under the terms of the Creative Commons Attribution License, which permits unrestricted use, distribution, and reproduction in any medium, provided the original author and source are credited. 
excreta/ feathers and admixture of other food grains. The clean graded materials were ground in the electric grinder to make fine flour and sieved by $80-100$ mesh sieves. The flour samples obtained were kept in airtight container before use.

\section{Preparation of chickpea flour}

Chickpea grains were cleaned to remove the foreign materials and then pearled in a hand-operated chakki for removal of husk. The pearled grains were ground in electric grinder to make fine powder and sieved by $80-100$ mesh sieve. The obtained flours were stored in airtight container before use.

\section{Preparation of full fat soy flour}

Soybean grains were thoroughly cleaned to remove the dust and other foreign materials. The clean grains were soaked in water for 4-6 hours and then autoclaved for 5 minutes in a pressure cooker. They were removed and dried directly in the sun for 3-4 days till the material was completely dried having 6-8\% moisture content. Soybean was then ground to make fine flour and sieved through $80-100$ mesh sieves. The flour samples obtained were kept in airtight container before use.

\section{Preparation of leafy vegetable powder}

The fresh leaves of methi were washed in tap water to remove the foreign materials and directly dried in the sun for 4-5 days till the material was completely dried having 6-8\% moisture content. They were ground in the electric grinder to make fine powder. The flour samples obtained were kept in air container before use.

\section{Preparation of various kinds of blends for making chapatti}

Four types of blends were prepared to make chapattis. A blends contained wheat flour and chickpea flour in different ratio viz., blend "A" consisting of 95:05, 90:10, 85:15, 80:20, 75:25 and 70:30 and denoted as $\mathrm{T}_{1}$ to $\mathrm{T}_{6}$; " $\mathrm{B}$ " blends consisting wheat flour and full fat soy flour in different ratio of 95:05, 90:10, 85:15 and 80:20 and denoted as $\mathrm{T}_{7}$ to $\mathrm{T}_{10}$. " $\mathrm{C}$ " blends consisting wheat flour, chickpea flour and soya flour in the ratio of 90:05:05 and 80:10:10 and denoted $\mathrm{T}_{11}$ and $\mathrm{T}_{12}{ }^{\text {." }} \mathrm{D}$ blends consisting wheat flour, chickpea flour, soy flour and leaves powder (methi) in the ratio of 75:10:10:05 and 70:10:10:10 denoted $T_{13}$ and $\mathrm{T}_{14}$. Wheat flour is used as control flour. These different blends were used in the preparation of various products.

\section{Preparation of chapatti /paratha / poories}

The different kinds of blends along with $100 \%$ wheat flour control were used to make the products after mixing with suitable water and small amount of salt (1.5\%). All the ingredients were taken in a plastic bowl mixed and hand kneaded to make dough by the addition of water $(60 \pm 6 \mathrm{ml}$ for $100 \mathrm{~g})$. The dough was then rolled up manually in a circle having $5 \mathrm{~cm}$ radius and thickness of about $0.16 \mathrm{~cm}$ and taken on an open pan maintained at $180-200{ }^{\circ} \mathrm{C}$ for without oil chapatti and with oil paratha, whereas poories were prepared by frying the rolled dough circles in oil at $200-220^{\circ} \mathrm{C}$ for $2-2.5 \mathrm{~min}$. After baking and frying they were subjected to sensory as well as nutritional evaluation by the standard procedures.

\section{Biochemical analysis of flour}

The biochemical analyses of the flours i.e. moisture content, fat content, protein content, ash content, crude fiber, total carbohydrate, fatty acids, minerals, calcium, phosphorus and iron were determined by A.O.A.C [11].

\section{Sensory evaluation of products}

The sensory evaluations of products were made by panel of 10 judges as described by Amerine et al. [12] on 9-point hedonic scale.

\section{Storage studies}

The shelf-life studies of flour were carried out in polyethylene and tin containers for a period of 3 months at ambient temperature. $100 \mathrm{gm}$ of each sample were packed and kept at room temperature for 90 days. All samples were drawn periodically after $0,30,60,90$, days and further analysis was carried out.

\section{Results and Discussion}

\section{Proximate composition of composite flours}

From Table 1 it can be seen that moisture content varied from 8.41 to $8.89 \%$ with the lowest $\mathrm{T}_{13}(8.41 \%)$ and highest is $\mathrm{T}_{4}(8.89 \%)$ The protein content in the various blended flours ranged from 11.80 to 15.98. The highest protein value was recorded in $\mathrm{T}_{13}$ and lowest in $\mathrm{T}_{0}$ (11.80\%). Fat content varied from 1.51 to $3.95 \%$ with the lowest in $\mathrm{T}_{0}$ (1.51\%) and highest in $\mathrm{T}_{13}$ (3.95\%).The highest amount of crude fibre was in $\mathrm{T}_{13}$ (2.05) and lowest in $\mathrm{T}_{0}(1.22 \%)$. Ash content varied from 2.03 to $2.70 \%$. The lowest value was observed in $\mathrm{T}_{0}(2.03 \%)$ and highest in $\mathrm{T}_{13}$ (2.70). The maximum amount of carbohydrates were recorded in $\mathrm{T}_{0}(74.22 \%)$ and lowest in $\mathrm{T}_{13}(65.99 \%)$. These findings were in line as observed by many investigators $[13,14]$.

From Table 2 it can be observed that calcium content ranged from 50 to $156.85 \mathrm{mg} / 100 \mathrm{~g}$ in the blended flours. The highest value recorded in $\mathrm{T}_{13}$ and lowest in $\mathrm{T}_{0}(50 \mathrm{mg} / 100 \mathrm{~g})$. The phosphorus content varied from 320 to $378 \mathrm{mg} / 100 \mathrm{~g}$ in blended flours. The highest phosphorus content was recorded in $\mathrm{T}_{13}(378 \mathrm{mg} / 100 \mathrm{~g})$ and lowered in $\mathrm{T}_{0}(320 \mathrm{mg} / 100 \mathrm{~g})$. The iron content varied from 5.3 to $12.11 \mathrm{mg} / 100 \mathrm{~g}$. The highest amount was recorded in $\mathrm{T}_{13}(12.11 \mathrm{mg} / 100 \mathrm{~g})$ and lowest in $\mathrm{T}_{0}(5.3 \mathrm{mg} / 100 \mathrm{~g})$. The increase in the nutritive value of flour by supplementation of other vegetables has been reported by many investigators $[15,16]$.

\section{Shelf life of the composite flours}

The shelf-life of the composite flours was evaluated by moisture content and fatty acid acidity. The various kinds of composite flours were stored in polyethylene bags and tin boxes for the period of 3 months at room temperature. The obtained results were tabulated in different Tables 3 to 6 .

\section{Changes in moisture content during storage}

From Table no $3 \& 4$ it was found that the moisture content of different kinds of blends varied from 8.41 to 10.20 in the polyethylene bags for the period of 3 months. The average mean values were $8.66 \%$ 0 days, $9.07 \%$ on 30 days, $9.71 \%$ on 60 days and on $10.02 \% 90$ days of different blends. This indicated that moisture content also did not change significantly during different storage periods. Similarly, storage of different kinds of composite flours was made in tin boxes for the period of 3 months at room temperature. The results showed that moisture content varied from 8.4 to $10.28 \%$. The average values of moisture in different kinds of flours $8.66 \%$ on 0 days, $9.18 \%$ on 30 days, $9.81 \%$ on 60 days and $10.10 \%$ on 90 days. The results indicate that moisture content did not varied significantly during different storage periods. The moisture contents of flours in both the containers were more or less the same. Butt et al studied the effect of moisture and 
Citation: Kadam ML, Salve RV, Mehrajfatema ZM, More SG (2012) Development and Evaluation of Composite Flour for Missi roti /chapatti. J Food Process Technol 3:134. doi:10.4172/2157-7110.1000134

Page 3 of 7

\begin{tabular}{|c|c|c|c|c|c|c|}
\hline \multirow{2}{*}{ Constituents (\%) } & \multicolumn{5}{|c|}{ Blends } & \multirow{2}{*}{ C.D. at $5 \%$} \\
\hline & $\mathrm{T}_{0}$ & $\mathrm{~T}_{4}$ & $\mathrm{~T}_{8}$ & $\mathrm{~T}_{12}$ & $\mathrm{~T}_{13}$ & \\
\hline Moisture & $8.8 \pm 0.02$ & $8.89 \pm 0.01$ & $8.12 \pm 0.00$ & $8.76 \pm 0.02$ & $8.41 \pm 0.04$ & NS \\
\hline Protein & $11.8 \pm 0.02$ & $12.86 \pm 0.05$ & $14.85 \pm 0.01$ & $15.37 \pm 0.01$ & $15.98 \pm 0.05$ & 0.247 \\
\hline Fat & $1.5 \pm 0.03$ & $2.26 \pm 0.00$ & $3.28 \pm 0.02$ & $3.28 \pm 0.03$ & $3.95 \pm 0.02$ & 1.671 \\
\hline Fibre & $1.2 \pm 0.02$ & $1.74 \pm 0.02$ & $1.45 \pm 0.04$ & $1.72 \pm 0.02$ & $2.05 \pm 0.01$ & 0.038 \\
\hline Ash & $2.0 \pm 0.03$ & $2.16 \pm 0.03$ & $2.23 \pm 0.02$ & $2.31 \pm 0.04$ & $2.70 \pm 0.01$ & 0.861 \\
\hline Carbohydrates & $74.2 \pm 0.04$ & $71.66 \pm 0.02$ & $67.87 \pm 0.05$ & $67.6 \pm 0.02$ & $65.99 \pm 0.02$ & 0.239 \\
\hline
\end{tabular}

*Values are average of 3 replications

Table 1: Proximate composition of different kinds of blends

\begin{tabular}{|c|c|c|c|c|c|c|}
\hline \multirow{2}{*}{ Constituents (\%) } & \multicolumn{5}{|c|}{ Blends } & \multirow{2}{*}{$\begin{array}{l}\text { C.D. } \\
\text { at } 5 \%\end{array}$} \\
\hline & $\mathrm{T}_{0}$ & $\mathrm{~T}_{4}$ & $\mathrm{~T}_{8}$ & $T_{12}$ & $\mathrm{~T}_{13}$ & \\
\hline Calcium & $50.00 \pm 0.01$ & $52.00 \pm 0.01$ & $67.00 \pm 0.03$ & $70.00 \pm 0.04$ & $56.85 \pm 0.03$ & 0.228 \\
\hline Phosphorus & $320.00 \pm 0.03$ & $322.50 \pm 0.03$ & $357.00 \pm 0.01$ & $358.00 \pm 0.01$ & $378.00 \pm 0.05$ & NS \\
\hline Iron & $5.30 \pm 0.04$ & $6.06 \pm 0.04$ & $5.92 \pm 0.04$ & $6.30 \pm 0.01$ & $12.11 \pm 0.04$ & 0.032 \\
\hline
\end{tabular}

${ }^{*}$ Values are average of 3 replications

Table 2: Mineral composition of different kinds of blends.

\begin{tabular}{|c|c|c|c|c|c|}
\hline \multirow{2}{*}{ Treatments } & \multicolumn{3}{|c|}{ Periods of storage (Days) } \\
\cline { 2 - 5 } & 0 & 30 & 60 & 90 \\
\hline$T_{0}$ & $8.80 \pm 0.01$ & $9.31 \pm 0.01$ & $9.92 \pm 0.01$ & $10.20 \pm 0.01$ \\
\hline$T_{4}$ & $8.89 \pm 0.01$ & $9.20 \pm 0.01$ & $9.97 \pm 0.01$ & $10.18 \pm 0.01$ \\
\hline$T_{8}$ & $8.72 \pm 0.01$ & $9.12 \pm 0.01$ & $9.88 \pm 0.01$ & $10.15 \pm 0.01$ \\
\hline$T_{12}$ & $8.76 \pm 0.01$ & $9.18 \pm 0.01$ & $9.94 \pm 0.01$ & $10.16 \pm 0.01$ \\
\hline$T_{13}$ & $8.41 \pm 0.01$ & $8.84 \pm 0.01$ & $9.32 \pm 0.01$ & $9.76 \pm 0.01$ \\
\hline
\end{tabular}

*Values are average of 3 replications

Table 3: Changes in moisture content of blended flours in polyethylene bags during different storage periods.

\begin{tabular}{|c|c|c|c|c|}
\hline \multirow{2}{*}{ Treatments } & \multicolumn{4}{|c|}{ Periods of storage (Days) } \\
\cline { 2 - 5 } & 0 & 30 & 60 & 90 \\
\hline$T_{0}$ & $8.80 \pm 0.02$ & $9.40 \pm 0.02$ & $9.98 \pm 0.05$ & $10.31 \pm 0.02$ \\
\hline$T_{4}$ & $8.89 \pm 0.03$ & $9.38 \pm 0.04$ & $10.12 \pm 0.06$ & $10.28 \pm 0.03$ \\
\hline$T_{8}$ & $8.72 \pm 0.05$ & $9.23 \pm 0.04$ & $9.97 \pm 0.04$ & $10.23 \pm 0.04$ \\
\hline$T_{12}$ & $8.76 \pm 0.01$ & $9.24 \pm 0.04$ & $10.02 \pm 0.03$ & $10.25 \pm 0.05$ \\
\hline$T_{13}$ & $8.41 \pm 0.04$ & $8.97 \pm 0.05$ & $9.44 \pm 0.02$ & NS \\
\hline
\end{tabular}

*Values are average of 3 replications

Table 4: Changes in moisture content of blended flours in Tin boxes during different storage periods.

\begin{tabular}{|c|c|c|c|c|c|}
\hline \multirow{2}{*}{ Treatments } & \multicolumn{4}{|c|}{ Period of storage (Days) } & \multirow{2}{*}{ C.D. at $5 \%$} \\
\hline & 0 & 30 & 60 & 90 & \\
\hline $\mathrm{T}_{0}$ & $0.112 \pm 0.02$ & $0.115 \pm 0.01$ & $0.118 \pm 0.03$ & $0.120 \pm 0.02$ & NS \\
\hline $\mathrm{T}_{4}$ & $0.161 \pm 0.04$ & $0.165 \pm 0.04$ & $0.161 \pm 0.04$ & $0.162 \pm 0.04$ & NS \\
\hline $\mathrm{T}_{8}$ & $0.181 \pm 0.01$ & $0.182 \pm 0.04$ & $0.190 \pm 0.01$ & $0.231 \pm 0.02$ & NS \\
\hline $\mathrm{T}_{12}$ & $0.152 \pm 0.03$ & $0.164 \pm 0.02$ & $0.181 \pm 0.03$ & $0.219 \pm 0.03$ & NS \\
\hline $\mathrm{T}_{13}$ & $0.169 \pm 0.04$ & $0.161 \pm 0.01$ & $0.171 \pm 0.03$ & $0.232 \pm 0.01$ & NS \\
\hline
\end{tabular}

*Values are average of 3 replications

Table 5: Changes in fatty acid acidity ( $\mathrm{mg}$ of $\mathrm{KOH} / 100 \mathrm{~g}$ of flour) of different kinds of blended flour in polyethylene bags during different storage periods.

\begin{tabular}{|c|c|c|c|c|c|}
\hline \multirow{2}{*}{ Treatments } & \multicolumn{4}{|c|}{ Period of storage (Days) } \\
\cline { 2 - 5 } & 0 & 30 & 60 & $0.130 \pm 0.02$ \\
\hline$T_{0}$ & $0.110 \pm 0.02$ & $0.121 \pm 0.03$ & $0.120 \pm 0.01$ & $0.181 \pm 0.03$ \\
\hline$T_{4}$ & $0.160 \pm 0.01$ & $0.181 \pm 0.04$ & $0.180 \pm 0.02$ & $\mathrm{NS}$ \\
\hline $\mathrm{T}_{8}$ & $0.183 \pm 0.03$ & $0.209 \pm 0.02$ & $0.221 \pm 0.03$ & $0.270 \pm 0.04$ \\
\hline $\mathrm{T}_{12}$ & $0.161 \pm 0.04$ & $0.164 \pm 0.04$ & $0.183 \pm 0.04$ & $0.232 \pm 0.03$ \\
\hline$T_{13}$ & $0.167 \pm 0.02$ & $0.181 \pm 0.01$ & $0.213 \pm 0.02$ & $0.242 \pm 0.02$ \\
\hline
\end{tabular}

*Values are average of 3 replications

Table 6: Changes in fatty acid acidity ( $\mathrm{mg}$ of $\mathrm{KOH} / 100 \mathrm{~g}$ of flour) of different kinds of blended flours in tin boxes during different storage periods. 
packaging on the shelf life of wheat flour and observed that multiwall polyethylene bags were found to be effective against moisture changes.

\section{Changes in fatty acid acidity during storage}

From Table 5 \& 6 it was found that the storage of different kinds of blended flours in polyethylene bags and tin boxes for the period of 90 days at ambient temperature revealed that fatty acid acidity was minimum (0.110-0.112) in control containing wheat flour alone However, the soy flour and chickpea blended flours contained higher values for fatty acid acidity (0.161-0.270). During storage of flours in both polyethylene bags and tin boxes showed that there were gradual increase in the fatty acid acidity in all the blends except control.
The values were higher in tin boxes (0.161-0.270) as compared to polyethylene bags (0.152-0.132). This indicates that polyethylene bags could be considered the safest for storage of different kinds of flours. Mahadevaiah et al. [17] studied the effect of flexible films packaging on Pulses and Cereal Flours and found a significant effect on cereal flours packed in polyethylene bags.

\section{Sensory quality characteristics of products}

From figure 1,2 and 3 it can be observed that different kinds of blends were developed to make chapaties and subjected to sensory evaluation. The results revealed that the sensory scores of various attributes viz; colour \& appearance, flavor, taste, texture and overall

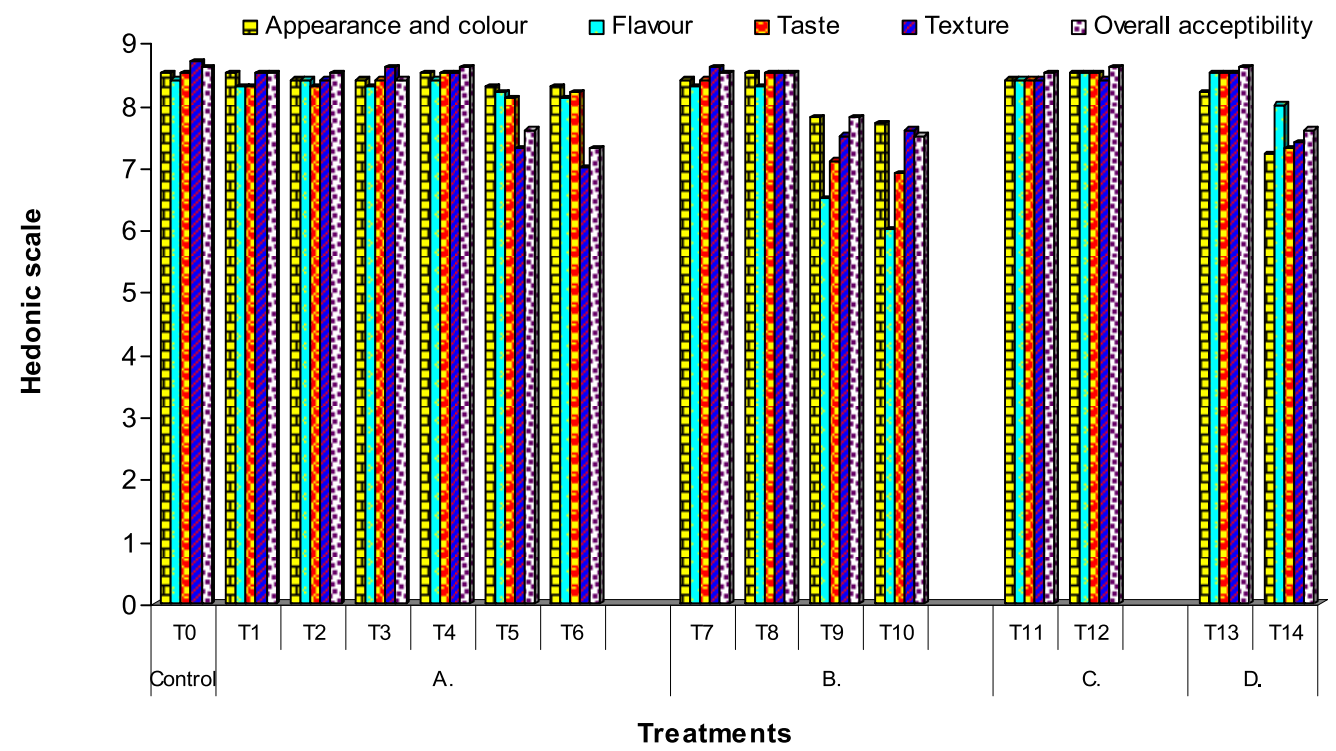

Figure 1: Sensory evaluation of chapatti made from different blends.

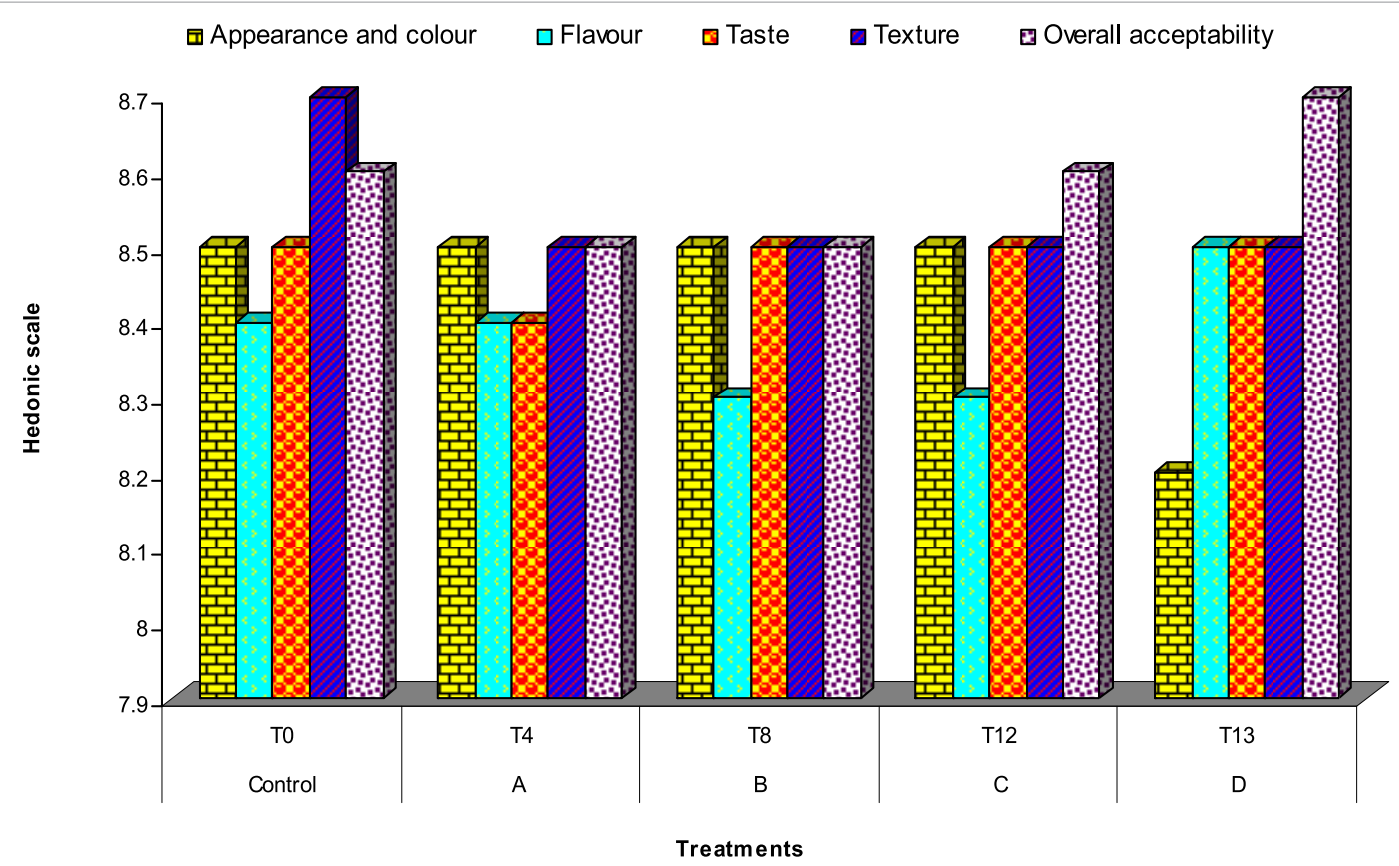

Figure 2: Sensory evaluation of paratha made from different blends. 


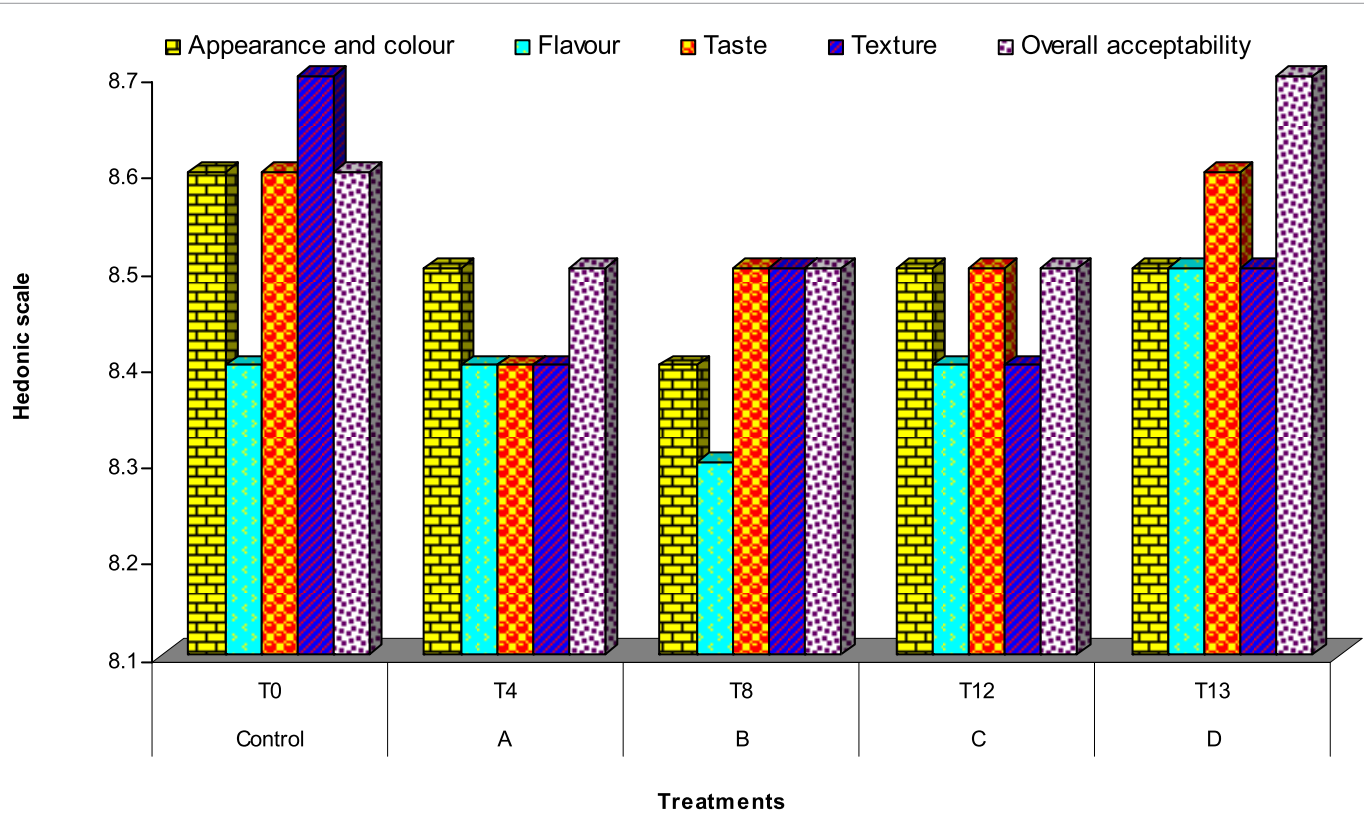

Figure 3: Sensory evaluation of poorie made from different blends.

acceptability (Figure 1) in between 8.3 to 8.7 in the products ( $\mathrm{T}_{1}$ to $\mathrm{T}_{4}$ ). However, on increasing the level of chickpea flour at the level of 25 and $30 \%$, there were a decrease in the textural quality and overall acceptability of the product $\left(\mathrm{T}_{5} \& \mathrm{~T}_{6}\right)$. This indicates that higher amount of chickpea flour beyond $20 \%$ affected the textural quality characteristics. On the basis of their observations $\mathrm{T}_{4}$ blend consisting of 80:20 (wheat flour: chickpea flour) could be considered the best for preparation of good quality of chapattis. Gomez et al. [18] studied the quality of cake prepared by using blend of wheat flour and cowpea and observed that the replacement of wheat flour by chickpea flour induced an increase in the initial firmness but cohesiveness and resilience diminished, increasing the tendency to hardening.

The supplementation of soy flour in wheat flour at the level of $5 \%$ to $20 \%$ for chapattis preparation revealed that the scores of various sensory attributes ranged in between 6.0 to 8.6 (Figure 1). The values were highest is $T_{7}$ and $T_{8}$ ranging in between 8.3 to 8.6 (Figure 1). However, values in $\mathrm{T}_{9}$ and $\mathrm{T}_{10}$ ranged in between 6.0 to 7.8 . This indicated that higher amount of soy flour decreased the sensory quality characteristics of the product. On the basis of their observation the supplementation of soy flour at the level of $10 \%$ could be considered the best from sensory point of view. The supplementation of both chickpea and soy flour at the level of 5 and $10 \%$ did not change the sensory quality of the chapattis which were the same as control. The scored of various sensory attributes ranged in between 8.4 to 8.6 (Figure 1) Thus, supplementation chickpea and soy flour both at the level of $10 \%$ each could also be considered good from sensory points of view. The supplementation of methi leaves powder at 5 and $10 \%$ showed that the values of various attributes ranged from 7.3 to 8.6 with lower values in $\mathrm{T}_{14}$. However, higher values were recorded in $\mathrm{T}_{13}$. This indicates that $5 \%$ methi powders could be considered best from sensory points of view. The sensory quality characters of poorie and paratha made from various kinds of blends containing $20 \%$ chickpea $\left(\mathrm{T}_{4}\right), 10 \%$ soy flour $\left(\mathrm{T}_{8}\right), 10 \%$ each chickpea and soy flour $\left(\mathrm{T}_{12}\right)$ and $10 \%$ chickpea flour, $10 \%$ soy flour and $5 \%$ dried methi leaves powder $\left(\mathrm{T}_{13}\right)$ concealed that the scores for various sensory attributes viz., colour and appearance, flavour, taste, texture and overall acceptability were good ranging in between 8.2 to 8.7 (Figure 2 and 3). This indicates that the good quality poorie and paratha could also be prepared from these blends. These findings support the previous results as observed by many investigators in chapati and other products [19-21]

This decrease in scores of the chapattis with increasing the level of soy flour incorporation may be attributed due to the typical taste and showed that chapattis prepared from blended wheat flour with more than $20 \%$ defatted soy flour had undesirable taste [22].

\section{Conclusion}

In the present investigations, different kinds of flours were made from wheat flour, chickpea flour, and soy flour and methi leaves powder and subjected to sensory evaluation in the form of chapatti, poorie and paratha. The results showed that wheat flour with $20 \%$ chickpea flour could be considered the best because all the sensory quality characteristics of the products were the same as control. At higher concentration of chickpea flour, there were slight decreases in the sensory quality. The supplementation of soy flour in wheat flour for chapatti preparation revealed that $10 \%$ processed soy flour were good without changing in the sensory characteristics of the chapatti. However, at higher concentration the values of sensory scores were found to decrease. The supplementation of soy flour in combination of chickpea in equal quantities i.e. $10 \%$ each did not change the sensory quality characteristics of chapattis as observed in the present study. These blends used in the preparation of poorie and paratha showed that sensory scores of these products were also the same as the chapattis suggesting that these blends could be well used in the preparation of poories and paratha. The storage of different kinds of flours in tin boxes and polyethylene bags revealed that there were no changes in the moisture content and fatty acid acidity of the flours during storage periods. Fatty acid acidity ranged in between 0.115 to 0.270 and moisture content 8.84 to $10.31 \%$. This indicates that containers did not influence much on the quality of blended flours. Thus, it was concluded that composite flour having high nutritional quality can be prepared from wheat flour with $10 \%$ chickpea and $10 \%$ soy flour and / or with $10 \%$ soy flour for making good quality of chaptties. The 
Citation: Kadam ML, Salve RV, Mehrajfatema ZM, More SG (2012) Development and Evaluation of Composite Flour for Missi roti /chapatti. J Food Process Technol 3:134. doi:10.4172/2157-7110.1000134

Page 6 of 7

supplementation of $5 \%$ methi powder can also be made to enhance the nutritional quality of flour particularly in minerals and fibres.

\section{References}

1. Shewry PR, Tatham AS (1994) Wheat endosperm proteins and their impact on the human mankind. In Martino al Cimino S (Ed.), Wheat kernel proteins: molecular and functional aspects .Italy, University of Tuscia, Viterbo: 19-26.

2. Dhingra S, Jood S (2001) Organoleptic and nutritional evaluation of wheat breads supplemented with soybean and barley flour. Food Chem 77: 479-488.

3. Nurul-Islam MD, Johansen HB (1987) Physical chemical tests-A basis for selecting the size of wheat flour. J Food Sci Technol 24: 136-138.

4. Bornet FR, Billaux MS, Messing B (1997) Glycaemic index concept and metabolic diseases. Int J Biol Macromol 21: 207-219.

5. Rizkalla SW, Bellisle F, Slama G (2002) Health benefits of low glycaemic index foods, such as pulses, in diabetic patients and healthy individuals. $\mathrm{Br} \mathrm{J}$ Nutr 88: S255-S262.

6. Anderson JW, Major AW (2002) Pulses and lipaemia, short- and longterm effect: potential in the prevention of cardiovascular disease. $\mathrm{Br} \mathrm{J}$ Nutr 88: S263-S271.

7. Eggum BO, Beame RM (1983) The nutritive value of seed proteins. Seed protein biochemistry, genetics and nutritive value (499-531).

8. Livingstone AS, Feng JJ, Malleshi NG (1993) Development and nutritiona quality evaluation of weaning foods based on malted, popped and dried wheat and chickpea. Int J Food Sci Technol 28: 35-43.

9. Dasappa I, Sai Manohar R, Jyotsna R, Venkateshwara Rao G (2004) Finger millet biscuits and a process for preparing the same. US Patent No.0191386, A1.

10. Iyer L, Singh U (1997) Functional properties of wheat and chickpea composite flours. Food Australia 49: 27-31.

11. A.O.A.C. (1984) Official methods of analysis, (14 ${ }^{\text {th }}$ Edn), Association of Official Agricultural Chemist. Inc, Arlington, V.A

12. Amerine MA, Pangborn RM, Roessler EB (1965) Principle of sensory evaluation of food. Academic Press, New York.

13. Macleod G, Ames J (1988) Soy flour and its improvements. CRC Critical Review. Food Sci Nutr 27: 219

14. Jambunathan $R$, Singh $U$ (1979) Chemical composition of desi and kabuli chick pea (Cicer aeritinum L.) cultivars, Proceedings: International Work Shop on Chickpea Improvement, ICRISAT, Hyderabad, 61-66.

15. Sawhney B, Kawatra BL (1986) Supplementary value of Beet (Beta vulgaris), Knol-khol (Brasica olarecea) and Turnip (Brasica rapa). Greens on the protein quality of wheat chapati. J Food Sci Technol 23 311.

16. Luthra Geeta, Balwinder sadana (1995) Potential of improving protein quality of wheat chapati by addition of Bathu (Chinopodium album), carrot (Daucus carota) and Radish (Raphanus sativus) leaves. J Food Sci Technol 32: 507

17. Mahadevaiah B, Kumar KR, Balasubrahmanyam (1977) Packaging Studies on Pulses and Cereal Flours in Flexible Films. Indian Food Packer: 1-7.

18. Gomez M, Oliete B, Rosell CM, Pando V, Fernandez E (2008) Studies on cake quality made of wheat-chickpea flour blend. LWT - Food Sci Technol 41: 17011709.

19. Tsen CC, Hoover WJ, Phillips D (1971) High protein bread. Bakers Dig 45: 20 s

20. Rawat A, Singh G, Mital BK, Mital SK (1994) Effect of soy fortification on quality characteristics of chapattis. J Food Sci Technol 31: 114.

21. Sharma YK, Subramanian N (1991) Studies on the soy-wheat flour blends in chapati making. The Indian Journal of Nutrition and Dietetics 28 : 228

22. Singh R, Singh G, Chauhan GS (1996) Effect of incorporation of defatted soy flour on the quality of biscuits. J Food Sci Technol 33: 355-357.

23. Ahluwalia P, Amarjeet K (2001) Studies on use of Isabgol (Psyllium mucilloid) Husk in atta for chapatti making. J Food Sci Technol 38: 75-78.

24. Bargale PC, Griffin Roger C (1991) Studies on modified atomosheric packaging of full fat soy flour. The Indian Journal of Nutrition and Dietetics 28: 118

25. Black CA (1965) Methods of soil science analysis. Am Soc Agros Inc Wisconsin.

26. Iwuoha IC, Anyadike AC, Eke OS (1997) The effect of flour blending on the physio-chemical and sensory quality of bread. J Food Sci Technol 34: 311-315

27. Banu D, Vaidehi MP (1998) Comparative evaluation of tandoori naans and kharaboondi enriched with full fat and defatted soy flours. The Indian Journal of Nutrition and Dietetics 35: 38

28. Dixit NK (2000) Studies on traditional food sattu from chickpea cultivars and its nutritional improvements. M.Sc. (Ag.) Thesis, Jawaharlal Nehru Krishi Vishwa Vidyalya, Jabalpur.

29. Viana SF, Guimarães VM, Jose IC, Oliveira MGE, Costa NMB, et al. (2005) Hydrolysis of oligosaccharides in soybean flour by soybean a-galactosidase. Food Chem 93: 665-670.

30. Gabriell BO, Sunday A (2001) Evaluation of pertormance of shea fat as a shortening of bread making. J Food Sci Technol 38: 149-151.

31. Gallagher E (2009) Gluten-free food science and technology. Black well publishing, UK

32. Gandhi AP, Khare SK, Krishna J (2001) Determination of residual hexane and microbiological status in de-oiled soybean meal. J Food Sci Technol 38: 260 262

33. Gandhi AP, Nichiket k, Jolly K, Shrivastav DC, Parihar VS, et al. (2001) Effect of incorporation of DFSF on quality of sweet biscuit. J Food Sci Technol 38: 502

34. Hira CK, Kochsar A, Sadana, Balwinder K, Sharma KK (1991) Protein, lysine, mineral and phenol contents of some Indian wheat (Triticum aestivum L.) Varieties. J Food Sci Technol 28: 112-113.

35. Indrani D, Savithri GD, Venkateswara Rao G (1997) Effect of defatted soy flour on the quality of buns. J Food Sci Technol 34: 440-442.

36. Joshi N, Vaidehi MP (1998) Effect of incorporation of defatted soybean in some common food products. The Indian Journal of Nutrition and Dietetics 36: 12-18

37. Kale FS (1985) Soybean: The use of soybean. Jain JD, Internationa Books and Periodicals Supply Service, New Delhi 30: 157.

38. Kaur M, Maan SK, Hira CK, Bajaj S (1988) Effect of Musk melon (Cumis melo) seed supplementation on the nutritive value of wheat chapati. J Food Sci Technol 25: 263-266.

39. Kulkarni SD, Joshi KC, Venkatraj J, Venkatraghavan U (1997) Extrusion cooking of soy cereal and tuber blends: Product properties. J Food Sci Techno 34: 509-512.

40. Leelavathi K, Vetrimani R, Haridas Rao P (1990) Changes in the functiona characteristics of wheat during soaking and subsequent germination. J Food Sci Technol 27: 349-354

41. Navita G, Sumathi S (1992) Effect of primary processing of dietary fibre profile of selected millets. J Food Sci Technol 29: 314-316.

42. Raja KCM (1985) Texture characteristics of cassava wheat dough and sensory properties of chapatti. J Food Sci Technol 23: 77-79.

43. Sewa R, Mishra BK, Nagarajan N (2001) Biscuit making quality of advance lines of wheat in India. J Food Sci Technol 38: 476-479.

44. Rathod KL, Williams SW (1973) Acceptance of soy-enriched wheat flour for use in chapati. The Indian Journal of Nutrition and Dietetics 10: 18.

45. Reddy N, Snehalatha, Neelam K, Rajkumar K, Vijaya N (1997) Content and in vitro availability of proteins and iron of different foods made from 
Citation: Kadam ML, Salve RV, Mehrajfatema ZM, More SG (2012) Development and Evaluation of Composite Flour for Missi roti /chapatti. J Food Process Technol 3:134. doi:10.4172/2157-7110.1000134

wheat effect of some food preparation methods. The Indian Journal of Nutrition and Dietetics 34: 150

46. Rossi M, Germondari I, Cansini P (1984) Composition of chickpea cultivars. Chemical composition, nutritional evaluation and oligosaccharide content. J Agric Food Chem 32: 811-814.

47. Saxena DC, Haridas Rao P (1995) Survey of the quality characteristics of Tandoon dough and Tandoori roti. J Food Sci Technol 32: 74

48. Shobana, Sangavan PS, Nainawatee HS, Lal BM (1976) Chemical composition of some improved varieties of pulses. J Food Sci Technol 13: 49-51.

49. Sidhu JS, Harinder K, Kaur A, Ram MB (1990) Functional and Chapati making properties of hull-less barley supplemented wheat flour. J Food Sci Technol 27: 311-313.

50. Neelam S, Usha MS, Chauhan GS (1990) Evaluation of some U.P. hill wheat for their physical, chemical, rheological and bread making characteristics. J Food Sci Technol 27: 198-201.

51. Singh $P$ (2009) Formulation and development of nutritious sattu and its evaluation. M.Sc. (Ag.) Thesis, Jawaharlal Nehru Krishi Vishwa Vidyalya, Jabalpur.

52. Ranjana S, Gurmukh S, Chauhan GS (2000) Development of soy-fortified biscuits and shelf life studies. J Food Sci Technol 37: 300-303.
53. Ranjana S, Gurmukh S, Chauhan GS (1997) Development of soy fortified biscuits: II. Standardization of fat and sugar levels. J Food Sci Technol b: 529 .

54.Singh N, Singh D, Chauhan GS (1994) Effect of defatting, coagulants and coagulation $\mathrm{pH}$ on soya protein isolates. J Food Sci Technol 31 : 117-121.

55.Singh PT, Soni GL, Singh R (1977) Biochemical evaluation of the common pulses of the Punjab state I. Proximate analysis. Journal of Research Punjab Agricultural University 14: 318-322.

56. Singh R, Singh G, Chouhan GS (1998) Development of soy-fortified biscuits: III. standardization of baking powder, skim milk powder, sodium stearoyl-2lactylate and glyceryl mono stearate levels. J Food Sci Technol 35: 227-230.

57. Sinha LK, Nawab A (1993) Preparation of medium fat-soy flour at smal scale. J Food Sci Technol 30: 14.

58. Sood DR, Dhindsa KS, Popli S, Wagle DS (1980) Compositional variations in different strains of soybean (Glycine max L.) Haryana Agricultural University Journal of Research 10: 198-203.

59. Venkatesh Murthy K, Sai Manohar R, Haridas Rao P (1998) Factors affecting sheeting characteristics of chapati dough using pnematic pressure extrusion. $J$ Food Sci Technol 35: 122-127. 